\title{
Non-indigenous macroinvertebrate species in Lithuanian fresh waters, Part 2: Macroinvertebrate assemblage deviation from naturalness in lotic systems and the consequent potential impacts on ecological quality assessment
}

\author{
K. Arbačiauskas ${ }^{(1)}, G$. Višinskiené(1), S. Smilgevičiené(1) \\ Received June 17, 2011 \\ Revised October 14, 2011 \\ Accepted October 17, 2011
}

Key-words: non-indigenous, river, biocontamination, high-impact species, ecological quality

\section{ABSTRACT}

The biological pressure represented by non-indigenous macroinvertebrate species (NIMS) should be addressed in the implementation of EU Water Framework Directive as this can have a direct impact on the 'naturalness' of the invaded macroinvertebrate assemblage. The biocontamination concept allows assessment of this deviation from naturalness, by evaluation of abundance and disparity contamination of an assemblage. This study aimed to assess the biocontamination of macroinvertebrate assemblages in Lithuanian rivers, thereby revealing the most high-impact non-indigenous species, and to explore the relationship between biocontamination and conventional metrics of ecological quality. Most of the studied rivers appeared to be impacted by NIMS. The amphipods Pontogammarus robustoides, Chelicorophium curvispinum and snail Litoglyphus naticoides were revealed as high-impact NIMS for Lithuanian lotic systems. Metrics of ecological quality which largely depend upon the richness of indicator taxa, such as the biological monitoring working party (BMWP) score and Ephemeroptera/Plecoptera/Trichoptera (EPT) taxa number, were negatively correlated with biocontamination, implying they could provide unreliable ecological quality estimates when NIMS are present. Routine macroinvertebrate water quality monitoring data are sufficient for generation of the biocontamination assessment and thus can provide supplementary information, with minimal extra expense or effort. We therefore recommend that biocontamination assessment is included alongside established methods for gauging biological and chemical water quality.

\section{RÉSUMÉ}

Les espèces de macroinvertébrés non-indigènes dans les eaux douces lituaniennes , Partie 2 : Les écarts à la naturalité des assemblages de macroinvertébrés dans les écosystèmes lotiques et les impacts potentiels conséquents sur l'évaluation de la qualité écologique

Mots-clés : espèces non-indigènes, rivières,
La pression biologique représentée par des espèces non-indigènes de macroinvertébrés (NIMS) devrait être abordée dans la mise en œuvre de la directive cadre sur l'eau car cela peut avoir un impact direct sur la « naturalité » des communautés de macroinvertébrés envahies. Le concept de biocontamination permet d'évaluer 
biocontamination, espèces à fort impact, qualité écologique cet écart de naturalité, par l'évaluation de la contamination en abondance et diversité d'une communauté. Cette étude vise à évaluer la biocontamination des assemblages de macroinvertébrés dans les rivières lituaniennes, révélant ainsi les espèces non indigènes à plus haute incidence, et d'explorer la relation entre la biocontamination et les métriques conventionnelles d'évaluation de la qualité écologique. La plupart des rivières étudiées semblent être touchées par les NIMS. Les amphipodes Pontogammarus robustoides, Chelicorophium curvispinum et les escargots Litoglyphus naticoides se révèlent comme NIMS à fort impact pour les systèmes lotiques lituaniens. Les métriques de qualité écologique, qui dépendent largement de la richesse de taxons indicateurs, tels que le score (BMWP) et le nombre de taxons Ephéméroptères/Plécoptères/Trichoptères (EPT), sont corrélés négativement avec la biocontamination, impliquant qu'ils pourraient fournir des estimations peu fiables de la qualité écologique, lorsque des NIMS sont présents. Les données de suivi de routine des macroinvertébrés pour l'estimation de la qualité de l'eau sont suffisantes pour la production de l'évaluation de la biocontamination et peuvent donc fournir des informations complémentaires, avec des frais ou un effort supplémentaire minimes. Nous recommandons donc que l'évaluation de la biocontamination soit incluse aux côtés des méthodes établies pour évaluer la qualité biologique et chimique de l'eau.

\section{INTRODUCTION}

Biological invasions are widely recognized as a component of anthropogenic environmental change (Vitousek et al., 1997) and represent an increasing threat to aquatic ecosystems and biodiversity worldwide (Sala et al., 2000; Cardoso and Free, 2008). Invasions of some nonindigenous species can radically change the structure and functioning of native communities and ecosystems (Ricciardi, 2001; Kelly et al., 2006; Van Riel et al., 2006), and may ultimately lead to the alteration of ecosystem-level services resulting in substantial economic loss (Spencer et al., 1991; Genovese, 2007). The EU Water Framework Directive (WFD) requires ecological status assessments of inland waters using various routinely monitored biological and physico-chemical indicators, with a principal objective of the WFD of maintaining high ecological status where it recently exists and attaining at least good ecological status in all freshwaters by 2015 (European Commission, 2000). Although not specifically mentioned, an issue of the non-indigenous macroinvertebrate species (NIMS) is addressed in the WFD as this biological pressure detracts from 'naturalness' (Cardoso and Free, 2008).

Biotic indices derived from benthic macroinvertebrates represent an important biological element used to assess quality of lotic systems such as rivers and streams for ecological classification (Armitage et al., 1983; Wright et al., 1984; Rosenberg and Resh, 1993). These indicators, which are based on native fauna, do not distinguish between native and NIMS and that may distort a true assessment of ecological status. In some cases the presence of NIMS may result in false elevation of quality status as these invaders may be more tolerant to pollution than the natives (MacNeil and Briffa, 2009). In addition, in other circumstances NIMS may falsely reduce quality estimates by suppressing macroinvertebrate indicator-species which are sensitive to ecological quality of the environment (Krisp and Maier, 2005; Gumuliauskaite and Arbačiauskas, 2008). Therefore, conventional estimates of ecological quality status should consider the presence of NIMS. Another task in evaluation of ecological quality status of aquatic ecosystems would be an elaboration of holistic method that incorporate a direct effect of NIMS on naturalness (Arbačiauskas et al., 2008; Panov et al., 2009). Achievement of these goals may not be simple, as improvement of the quality of environmental may favour NIMS and consequently, increase their domination of macroinvertebrate assemblages (Leuven et al., 2009). Therefore, NIMS impact on native macroinvertebrate assemblages and consequently water quality monitoring needs to be evaluated. 
Although biological invasions may be perceived as 'biological pollution' of aquatic ecosystems (Elliott, 2003), the detrimental impacts of NIMS on resident communities and ecosystems (sensu Elliot, 2003) usually remain unmeasured, as quantitative assessment of disturbances is difficult and requires comprehensive research (Molnar et al., 2008). In contrast, the WFD requires easily measureable parameters which can be derived from data of routine biological monitoring of inland waters. Therefore, a more practical approach to assess the NIMS impact, may be to assume that their impact on the assemblage is proportional to their proportion in structure of recipient assemblage, e.g. abundance or taxonomic composition, and measure it. Such a method has been proposed by Arbačiauskas et al. (2008) and this evaluates a deviation or detraction from naturalness in structure of resident assemblages due to NIMS presence, without implication of any detrimental or other impacts. This concept of deviation from naturalness has been named as 'biological contamination' or biocontamination (Arbačiauskas et al., 2008; Panov et al., 2009) and has received support in several recent studies (Leuven et al., 2009; MacNeil and Briffa, 2009; MacNeil et al., 2010). The method includes both an assessment of the relative abundance of NIMS (abundance contamination) and an assessment of the proportion of non-indigenous orders (interpreted as disparity contamination, as different macroinvertebrate orders represent particular ecomorphological groups associated with specific feeding patterns, therefore, the higher taxonomic richness provides a proxy of disparity) within an assemblage. This allows status ranking into five quality classes (Arbačiauskas et al., 2008). In the original study these quality classes were referred as 'ecological status' classes. Although the meaning of ecological status has been thoroughly explained, 'NIMS-specific status of naturalness' would be preferable for the designation of status of the macroinvertebrate assemblage with respect to the presence of NIMS. This clarification would exclude any misinterpretation, as conventionally ecological status is primarily associated with water quality and hydromorphology.

The purpose of this study was to assess the deviation from naturalness of macroinvertebrate assemblages in Lithuanian lotic systems by application of the biocontamination concept. A secondary aim was to test which NIMS were associated with the most severe biocontamination of recipient macroinvertebrate assemblages. This is vital, as early recognition and prediction of 'worst' NIMS (i.e. those which are capable of significantly altering native communities and cause environmental damage) is of primary importance for setting priorities in NIMS control and management (Ricciardi, 2003; Panov et al., 2009). A final aim was to explore a relationship between metrics of biocontamination and established metrics of ecological quality, as this would test a hypothesis that biocontamination detrimentally affects the richness of environment quality sensitive taxa, therefore distorting estimates by metrics which are largely dependent upon the richness of indicator species.

\section{MATERIAL AND METHODS}

Surveys of 67 sites in 14 Lithuanian rivers were performed in August 2007 and AugustSeptember 2008 (the lower and the middle sections of the Nemunas River (7 and 10 sites, correspondingly) and the Minija (5), Šešupè (4), Nevėžis (5), Neris (7), Merkys (1), Baltoji Ančia (2), Žeimena (4), Šventoji (4), Venta (4), Mūša (4), Lèvuo (3), Nemunèlis (5) and Dysna (2) rivers) (Figure 1). Semi-quantitative dip-net samples were collected from shoreline to $1.2 \mathrm{~m}$ depth covering all types of substrate and macrophytes by two persons for 15 min timed sampling efforts as regards the Nemunas samples or $10 \mathrm{~min}$ timed sampling efforts as regards samples for several other rivers (Figure 1), allowing assessment of macroinvertebrate assemblage structure and species abundance estimated as catch per timed sampling effort.

Assessment of biological contamination at study sites (biocontamination index) was derived from two metrics; the abundance contamination (AC) index estimated as proportion of NIMS specimens among all sampled animals and the disparity contamination (DC) index, calculated as the proportion of non-indigenous orders among all recorded macroinvertebrate orders (also referred to as richness contamination at ordinal taxonomic rank). Application of this method 


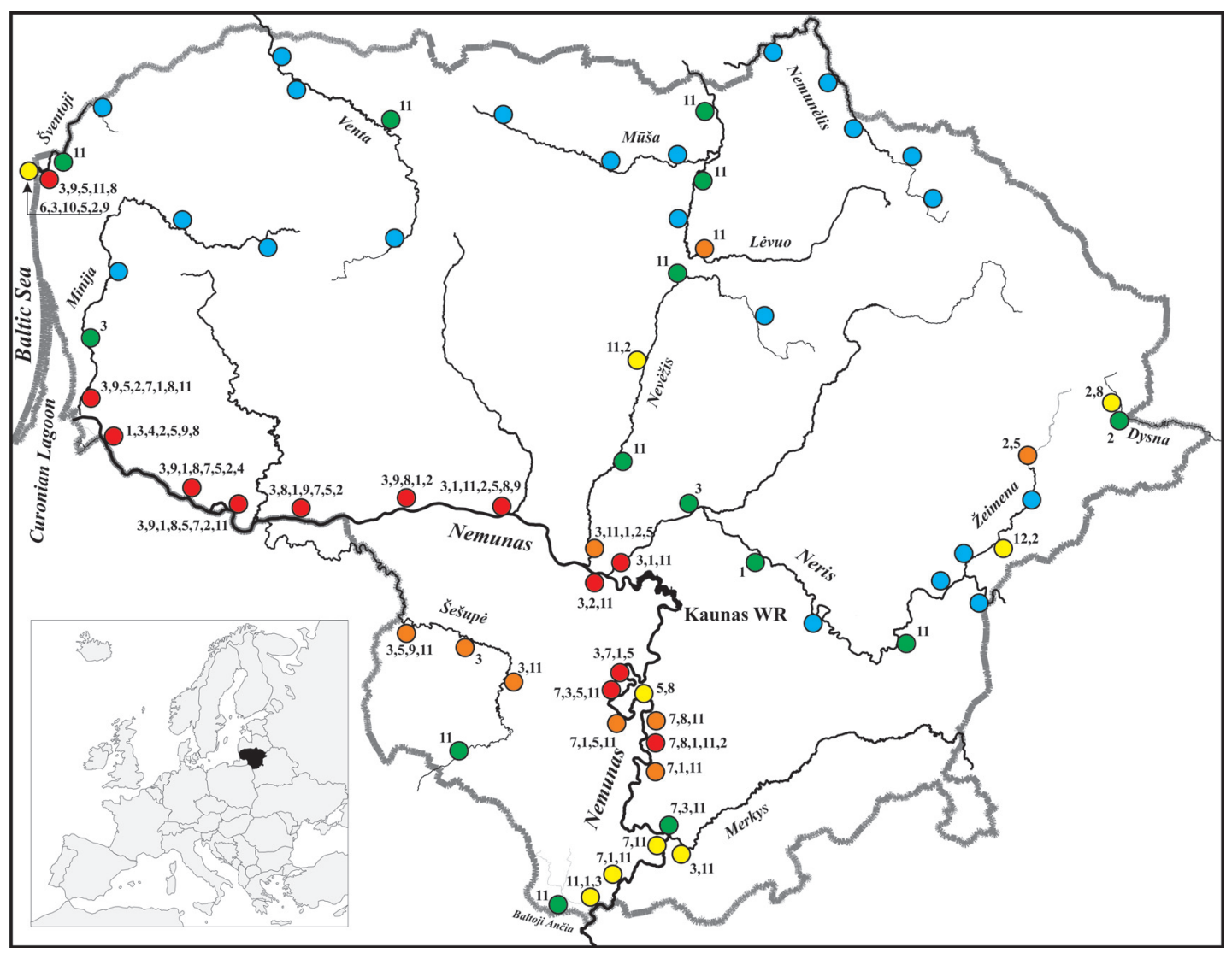

\section{Figure 1}

Assessment of NIMS-specific status of naturalness of river study sites. Blue, green, yellow, orange and red circles indicates five biocontamination classes: no, low, moderate, high and severe biocontamination, correspondingly. NIMS recorded at study sites indicated by numbers arranged in accordance to their abundance: Lytoglyphus naticoides (1), Dreissena polymorpha (2), Pontogammarus robustoides (3), Obesogammarus crassus (4), Chaetogammarus warpachowskyi (5), Gammarus tigrinus (6), Chelicorophium curvispinum (7), Paramysis lacustris (8), Limnomysis benedeni (9), Palaemon elegans (10), Orconectes limosus (11), and Pacifastacus leniusculus (12).

\section{Figure 1}

Évaluation du statut de naturalité des sites d'étude en rivière. Les cercles bleu, vert, jaune, orange et rouge indiquent cinq classes de biocontamination : aucune, faible, modérée, élevée et biocontamination sévère, respectivement. NIMS enregistrées sur les sites d'étude indiquées par des nombres disposés en fonction de leur abondance : Lytoglyphus naticoides (1), Dreissena polymorpha (2), Pontogammarus robustoides (3), Obesogammarus crassus (4), Chaetogammarus warpachowskyi (5), Gammarus tigrinus (6), Chelicorophium curvispinum (7), Paramysis lacustris (8), Limnomysis benedeni (9), Palemon elegans (10), Orconectes limosus (11), et Pacifastacus leniusculus (12).

allows the ranking of study sites into five quality classes of NIMS-specific status of naturalness: no biocontamination, high status; low biocontamination, good status (proportions 0.01-0.10); moderate biocontamination, moderate status $(0.11-0.20)$, high biocontamination, poor status (0.21-0.50); and severe biocontamination, bad status (>0.50) (Arbačiauskas et al., 2008). Richness contamination at family taxonomic rank was calculated as well, as this metric can also be applied in biocontamination estimates. To assess the ecological quality of macroinvertebrate assemblages in a conventional sense, Biological Monitoring Working Party (BMWP) scores and Average Score per Taxon (ASPT) values were calculated with exclusion of the NIMS. Richness of indicator taxa was estimated by Ephemeroptera, Plecoptera and Trichoptera (EPT) species number (Rosenberg and Resh, 1993). 
To generate integrated estimates of biocontamination on a continuous scale, numeric values of abundance or disparity contamination indices, whichever were larger and designated the status class, were utilized. Spearman rank $\left(r_{\mathrm{S}}\right)$ correlation was applied to test relationships between biocontamination and macroinvertebrate metrics of ecological water quality.

Association between the NIMS abundance (evaluated as ind. $10 \mathrm{~min}^{-1}$ ) and the estimates of abundance and disparity contamination and other explanatory (environmental and spatial) variables was analysed by redundancy analysis (RDA). Analysis was performed on a similarity (correlation) matrix based on square-root transformed species abundances (to down-weight the effect of the most abundant species) and the Hellinger transformation of species data (to reduce the arch effect because of the presence of double zeros) which provided the Hellinger distance matrix (Legendre and Gallagher, 2001; Zuur et al., 2007). Environmental variables (matrix X) included biocontamination indices, macroinvertebrate metrics of ecological quality and log-transformed estimates of river discharge at study sites (Gailiušis et al., 2001) to account for river size effect.

Spatial variables (matrix W) were generated using a network approach by coding the nodes of inflow of studied tributaries into the Nemunas River. The downstream dispersal of NIMS in the Nemunas River basin from outside Lithuania and places of deliberate introduction was hypothesized to be primarily responsible for biocontamination of flowing waters. Thus, each study site was characterized by the sequence of nodes along the direct path connecting the site to the base of the hydrographic tree located at the uppermost tributary (Magnan et al., 1994; Legendre and Legendre, 1998). The Nevéžis and Lèvuo rivers are interconected by the canal which probably has enabled the invasion of the Mūša River basin by the spine-cheek crayfish (Arbačiauskas et al., 2011). Therefore, this basin was assigned to be a branch of the Nemunas hydrographic tree (Figure 1).

Species (NIMS) abundance variation was analysed against the environmental and spatial variables using simple RDA and partial RDA, and the total variation was partitioned into four independent fractions: "pure" environmental, "pure" spatial, spatial fraction of environmental variation, and residual (Legendre and Legendre, 1998). The statistical significance of the environmental and spatial fractions was evaluated by Monte Carlo permutation tests, with analysis performed using Brodgar 2.6.5 software.

\section{RESULTS}

A total of 266 macroinvertebrate taxa belonging to 25 macroinvertebrate orders and class Oligochaeta were identified during the river survey. They included 12 NIMS from two molluscan and three crustacean orders (Table I), which comprised less than $5 \%$ of recorded taxa. The number of NIMS per site varied from 0 (absent) to 8 species in the lower section of the Nemunas River. NIMS presence and biocontamination class at study sites are shown in Figure 1, and metrics of biocontamination and ecological quality status are provided in Annex.

The highest abundance contamination (above 0.8) was recorded at two sites in the lower section of the Nemunas River including a section above the Kaunas water reservoir (WR), and the largest disparity contamination (at 0.3) was also found in the same river (Annex). All of the lower section and several places in the middle section of the Nemunas River were classified as severely biocontaminated (Figure 1). Severely biocontaminated sites were also found in the lowest stretches of the Minija and Neris rivers and one site in the Šventoji River (Figure 1). Sites with high biocontamination were identified in the middle section of the Nemunas River, the Šešupe River and the lowest stretch of the Nevėžis River. Sites exhibiting high biocontamination were also detected in the Levvuo and Žeimena rivers and these were due to the high relative abundances of the spine-cheek crayfish Orconectes limosus and mussel Dreissena polymorpha. Sites devoid of NIMS in the Nemunas River basin were recorded in the Minija, Neris and Žeimena rivers, and the upper section of the Nevezžis River (Figure 1). The NIMS-specific status of naturalness in the other rivers surveyed, except the Šventoji River which empties directly into the Baltic Sea, tended to be higher. Only one river surveyed, the Nemunelis River, appeared to be devoid of NIMS (Figure 1). 


\section{Table I}

Macroinvertebrate orders and non-indigenous macroinvertebrate species (NIMS) recorded in surveyed rivers. Higher rank taxonomy given in accordance to http://www.faunaeur.org. NB Oligochaeta were identified to class taxonomic rank.

Tableau I

Ordres de macro-invertébrés et espèces non-indigènes de macroinvertébrés (NIMS) rencontrés dans les rivières étudiées. Niveau taxonomique le plus élevé donné conformément au site http://www.faunaeur.org. NB Les oligochètes ont été identifiés au niveau taxonomique de la classe.

\begin{tabular}{|c|c|c|}
\hline Higher taxon & Order & NIMS \\
\hline \multicolumn{3}{|c|}{$\begin{array}{l}\text { Phylum Platyhelminthes } \\
\text { Subphylum Turbellaria } \quad \text { Seriata }\end{array}$} \\
\hline \multicolumn{3}{|c|}{ 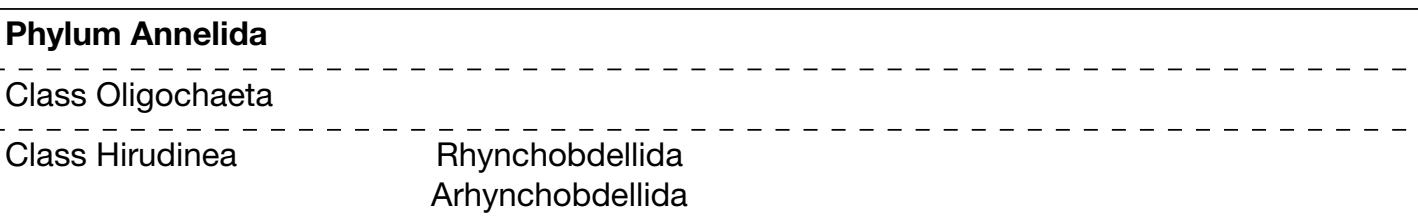 } \\
\hline \multirow{2}{*}{\multicolumn{3}{|c|}{$\begin{array}{l}\text { Phyllum Mollusca } \\
\text { Class Gastropoda } \\
\text { Class Bivalvia } \\
\text { Phyllum Arthropoda }\end{array}$}} \\
\hline & & \\
\hline \multicolumn{3}{|c|}{ 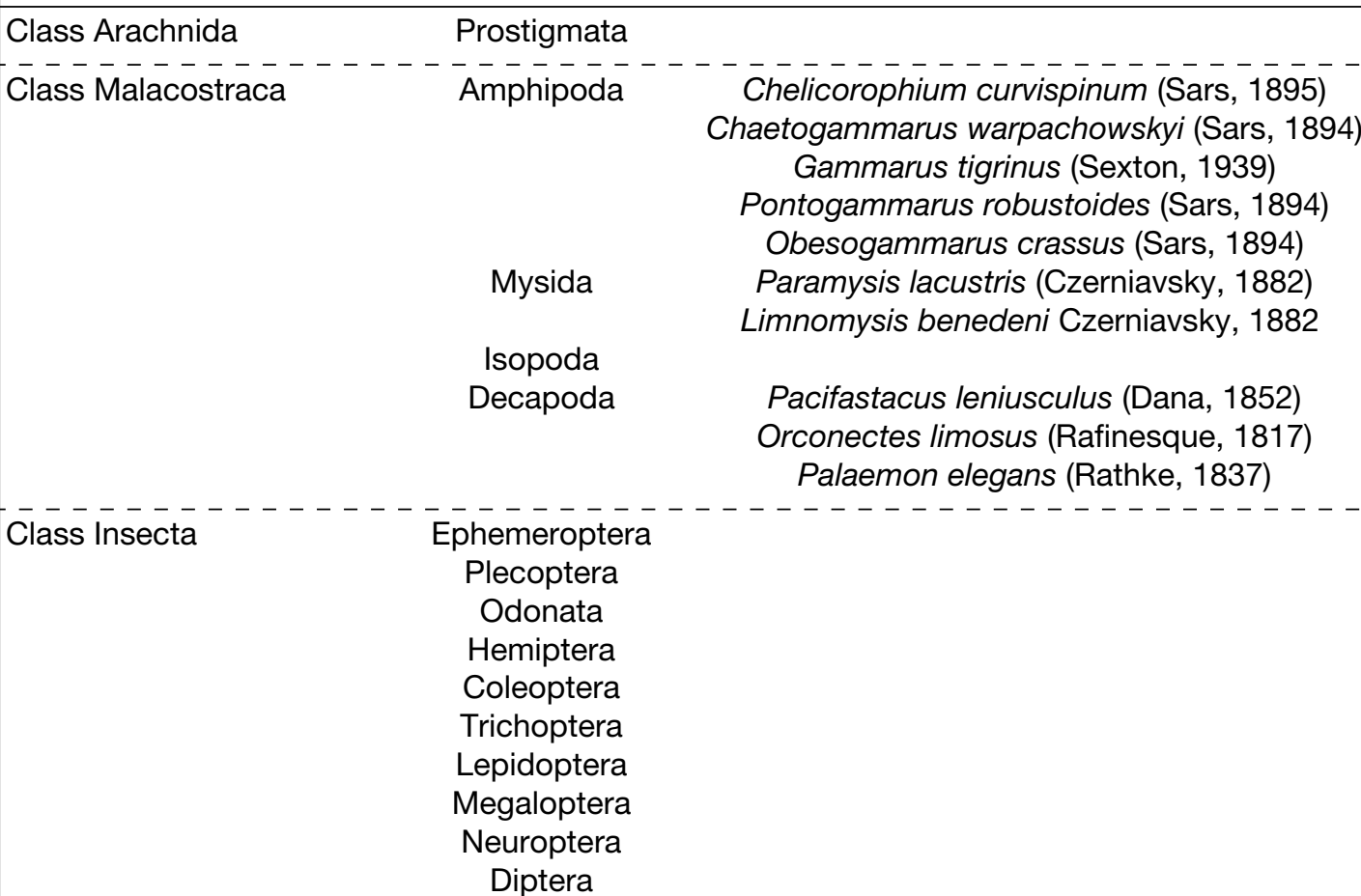 } \\
\hline
\end{tabular}

Variation of estimates of abundance, disparity and richness at family rank contamination within the different biocontamination classes indicated that separation between the low and moderate NIMS-specific status of naturalness depended upon disparity contamination. In contrast, the 


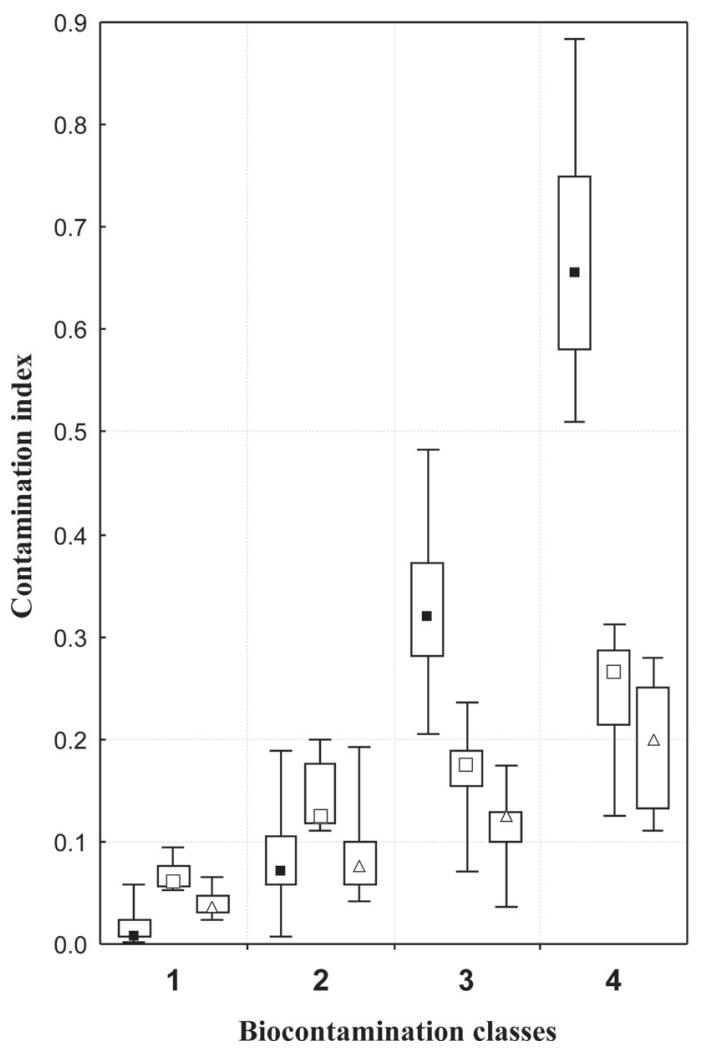

Figure 2

Variation (median, range, quartiles) of estimates of abundance (closed squares), disparity (open squares) and richness at family taxonomic rank (open triangles) contamination indices within different biocontamination classes: low (1), moderate (2), high (3) and severe (4). Biocontamination metrics were measured as relative NIMS abundance and proportions of non-indigenous orders and families within an assemblage, correspondingly.

\section{Figure 2}

Variation (médiane, étendue, quartiles) des estimations de l'abondance (carrés pleins), de la disparité (carrés vides) et de la richesse au rang taxonomique de la famille (triangles vides) des indices de contamination au sein des classes différentes de biocontamination: faible (1), modérée (2), haute (3) et sévère (4). Les métriques de biocontamination ont été mesurées en abondance NIMS et les proportions relatives des non-autochtones par ordres et par familles au sein d'un assemblage, respectivement.

poor and bad statuses were classified by abundance contamination. When comparing richness contamination at family and ordinal (i.e. disparity contamination) ranks, the latter metric provided higher index values (Figure 2).

Association between NIMS abundance and biocontamination components was analysed over 45 river sites where NIMS were recorded. Only those NIMS which occurred at more than two study sites were considered in the calculations (Figure 1). Consequently, the molluscs D. polymorpha and Lithoglyphus naticoides, the amphipods Pontogammarus robustoides, Chaetogammarus warpachowskyi and Chelicorophium curvispinum, the mysids Paramysis lacustris and Limnomysis benedeni, and the crayfish $O$. limosus were included into the analysis. While the brackish water shrimp Palaemon elegans, the signal crayfish Pacifastacus leniusculus and the amphipods Obesogammarus crassus and Gammarus tigrinus were excluded. As estimates of BMWP and EPT were strongly correlated $(r=0.84)$, the BMWP was omitted from the redundancy analysis to avoid collinearity problems.

Results of RDA of species (NIMS) variation constrained separately by environmental and spatial variables, and those of partial RDA constrained by environmental variables using spatial variables as covariates are provided in Table II and Figure 3. A simple RDA with environmental variables suggested that the amphipod $P$. robustoides, the gastropod $L$. naticoides and the 


\section{Table II}

Canonical coefficients for the four best individual predictor terms in redundancy analyses of species (NIMS) matrix as response variables: simple RDA constrained by the matrix of environmental variables $(X)$ (RDA-1), simple RDA constrained by the matrix of spatial variables (W) (RDA-2) and partial RDA constrained by $X$ using $W$ as matrix of covariates (partial RDA). Eigenvalues for axis 1 and axis 2 were 0.190 and 0.059 (RDA-1), 0.105 and $0.058(R D A-2)$ and 0.198 and 0.030 (partial RDA), correspondingly. Environmental variables: abundance contamination (AC) measured as relative NIMS abundance, disparity contamination (DC) assessed as proportion of non-indigenous orders, river discharge at study site (DIS), ASPT score and EPT taxa. Spatial variables: nodes 1, 3, 4 and 5 indicating inflows of the Baltoji Ančia, Neris, Nevéžis and Šešupé rivers (see Figure 1). Forward selection of predictors was applied. Probabilities for individual predictors were based on permutations $(\mathrm{n}=999)$ using raw data.

\section{Tableau II}

Coefficients canoniques pour les quatre meilleurs termes prédicteurs dans les analyses de redondance de la matrice des espèces (NIMS) comme variables de réponse : RDA simples contraintes par la matrice des variables environnementales $(X)(R D A-1)$, RDA simples contraintes par la matrice des variables spatiales (W) (RDA-2) et RDA partielle limitée par X en utilisant W comme matrice de covariables (RDA partielle). Les valeurs propres pour l'axe 1 et 2 étaient 0,190 et 0,059 (RDA-1), 0,105 et 0,058 (RDA-2) et 0,198 et 0,030 (RDA partielle), respectivement. Variables environnementales : contamination en abondance (AC) mesurée par l'abondance relative des NIMS, (DC) évaluée par la proportion des ordres non-autochtones, débit des rivières au site d'étude (DIS), score ASPT et taxons EPT. Variables spatiales: les nœuds 1, 3, 4 et 5 indiquant la confluence des rivières Baltoji Ančia, Neris, Nevéžis et Šešupẻ (voir Figure 1). La sélection progressive de prédicteurs a été appliquée.

\begin{tabular}{|l|c|c|c|c|}
\hline Analysis & Predictor & Axis 1 & Axis 2 & Probability \\
\hline RDA-1 & DC & 0.645 & 1.045 & 0.001 \\
& DIS & 0.332 & -1.095 & 0.009 \\
& AC & 0.110 & -0.182 & 0.91 \\
& ASPT & 0.025 & -0.115 & 0.68 \\
\hline RDA-2 & Node 5 & 0.087 & 0.922 & 0.038 \\
& Node 3 & 1.027 & -0.496 & 0.12 \\
& Node 1 & -0.804 & -0.438 & 0.012 \\
& Node 4 & -0.002 & -0.333 & 0.74 \\
\hline Partial RDA & DC & 0.757 & 1.369 & 0.001 \\
& DIS & 0.635 & -0.515 & 0.18 \\
& AC & -0.200 & -1.417 & 0.93 \\
& EPT & -0.303 & -0.499 & 0.57 \\
\hline
\end{tabular}

mysid P. lacustris were related to abundance contamination, while the amphipod C. warpachowskii and the mysid L. benedeni, and the amphipod C. curvispinum were associated with disparity contamination and river size, correspondingly (Figure 3a). Further analysis, a RDA with spatial variables in particular, showed the presence of significant spatial structure in species variation (Table II). A partial RDA controlling for the effect of the spatial pattern finally revealed that the estimates of abundance contamination and river discharge were highly correlated, and the high abundance of the amphipods $P$. robustoides and $C$. curvispinum was associated with these predictors (Figure 3b). Indeed, the high abundance contamination was a characteristic of the lower stretch of the Nemunas River. Whilst the pontogammarid and C. curvispinum were the dominant species in 10 and 2 cases (of 13) of severe biocontamination, correspondingly. C. curvispinum was at its most abundant in the middle section of the Nemunas river where $P$. robustoides was absent or scarce. Ponto-Caspian mysids and the gastropod 


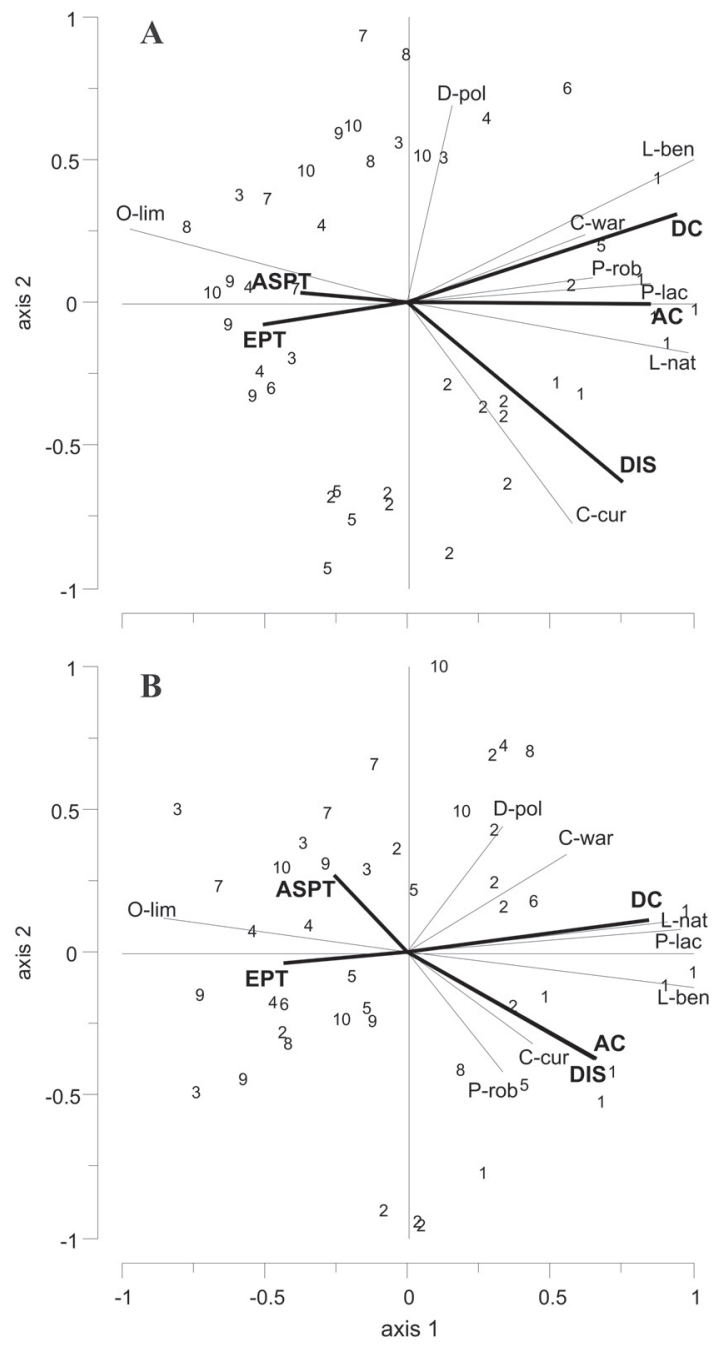

\section{Figure 3}

Correlation triplots for river biocontamination data obtained by $R D A(A)$ and partial $R D A$ using spatial variables as covariates (B). Analysis was based on the Hellinger distance matrix. Species: Lytoglyphus naticoides (L-nat), Dreissena polymorpha (D-pol), Pontogammarus robustoides (P-rob), Chaetogammarus warpachowskyi (C-war), Chelicorophium curvispinum (C-cur), Paramysis lacustris ( $P$-lac), Limnomysis benedeni (L-ben) and Orconectes limosus $(O-l i m)$. Environmental variables: abundance $(A C)$ and disparity $(D C)$ contamination measured as relative NIMS abundance and proportion of non-indigenous orders within an assemblage, correspondingly, river discharge at study site (DIS), ASPT score and EPT taxa. River study sites (45 in total): lower Nemunas section (1); middle Nemunas section (2); Šešupè (3); Nevéžis (4); Neris (5); Minija (6); Baltoji Ančia and Merkys (7); Šventoji (8); Mūša, Lèvuo and Venta (9); Zeimena and Dysna (10).

\section{Figure 3}

Corrélation triplot des données de biocontamination de rivières obtenue par RDA (A) et RDA partielle en utilisant des variables spatiales comme covariables (B). L'analyse était basée sur la matrice de distance de Hellinger. Espèce: Lytoglyphus naticoides (L-nat), Dreissena polymorpha (D-pol), Pontogammarus robustoides (P-rob), Chaetogammarus warpachowskyi (C-war), Chelicorophium curvispinum (C-cur), Paramysis lacustris (P-lac), Limnomysis benedeni (L-ben) et Orconectes limosus (O-lim). Variables d'environnement : la contamination en abondance (AC) et en disparité (DC) mesurée comme l'abondance relative de NIMS et la proportion des ordres des non-autochtones au sein d'un assemblage, le débit des rivières au site d'étude (DIS), le score ASPT et les taxons EPT. Sites d'étude en rivière (45 au total) : la section inférieure du Niémen (1) ; section médiane du Niémen (2) ; Šešupè (3) ; Nevėžis (4) ; Neris (5) ; Minija (6) ; Baltoji Ančia et Merkys (7) ; Šventoji (8) ; Mūša, Lèvuo et Venta (9) ; Žeimena et Dysna (10). 


\section{Table III}

Partition of the total variation in species (NIMS) data (matrix Y) into components, and proportions of these fractions explained by the first two axis. Probabilities indicate Monte Carlo significance test of all canonical axes based on permutations $(\mathrm{n}=999)$ using raw data.

Tableau III

Répartition de la variation totale des données en espèces (NIMS) (matrice Y) dans les composantes canoniques et les proportions de ces fractions expliquées par les deux premiers axes. Les probabilités indiquent la signification par le test de Monte Carlo de tous les axes canoniques basé sur les permutations $(n=999)$ utilisant des données brutes.

\begin{tabular}{|lccc|}
\hline Fraction of variation & Proportion of variation of $Y$ & Probability & $\begin{array}{c}\text { Proportion explained by } \\
\text { two axes }\end{array}$ \\
\hline Pure environmental & 0.261 & 0.001 & 0.87 \\
\hline Pure spatial & 0.183 & 0.005 & 0.70 \\
\hline Shared & 0.030 & & \\
\hline Residual & 0.526 & & \\
\hline
\end{tabular}

L. naticoides were related to the sites of the highest disparity contamination (Figure 3b), indicating that their abundances were larger at sites with higher NIMS richness than elsewhere. The amphipod $C$. warpachowskyi also tended to be more numerous at sites of higher disparity contamination. Whereas $D$. polymorpha abundance was unrelated to biocontamination levels. In contrast to many other invaders, the spine-cheek crayfish O. limosus was at its most abundant in sites of low biocontamination, with the greatest recorded in the places devoid of the other NIMS. Analysis of results also revealed that metrics of biocontamination and ecological status over study sites invaded by NIMS were negatively correlated and among recorded NIMS only $\mathrm{O}$. limosus tended to be more numerous at sites of higher ecological quality as measured by macroinvertebrate bioindicators (Figure 3).

Partitioning of the NIMS variation indicates that the environmental and the spatial variables together accounted for $47.4 \%$ of the total variation. The "pure" environmental and spatial components were significant and explained 26.1 and $18.3 \%$ of variation, correspondingly (Table III). The "pure" fraction of variation constrained by biocontamination metrics was at $8.8 \%$ (partial RDA with other environmental and spatial variables as covariates, Monte Carlo permutation $(n=999)$ test, $P=0.01)$.

The relationship between biocontamination and ecological quality was also explored over all river study sites. Because sampling effort may affect taxa richness and consequently values of metrics strongly associated with indicator taxa richness, BMWP and EPT estimates for the Nemunas River were analysed separately from the other rivers. BMWP scores and biocontamination estimates were negatively correlated in both groups (Figure 4). The same pattern was revealed for the EPT taxa richness; correlations for the Nemunas and other rivers were $r_{\mathrm{S}}=-0.58\left(t_{15}=-2.75, P=0.015\right)$ and $r_{\mathrm{S}}=-0.46\left(t_{48}=-3.57, P<0.001\right)$, correspondingly. Covering all study sites, the ASPT scores, although weaker than that for other ecological quality metrics, were also negatively related to biocontamination $\left(r_{S}=-0.29, t_{65}=-2.48, P=0.016\right)$, but the effect was absent $(P>0.3)$ when analyzing the Nemunas and the other rivers separately.

\section{DISCUSSION}

With reference to the biocontamination concept (Arbačiauskas et al., 2008), we assessed the deviation from naturalness of macroinvertebrate assemblages due to NIMS presence in large and medium-sized Lithuanian rivers. The method provided clearly interpretable and robust information on structural organisation of benthic assemblages and allowed the classification 


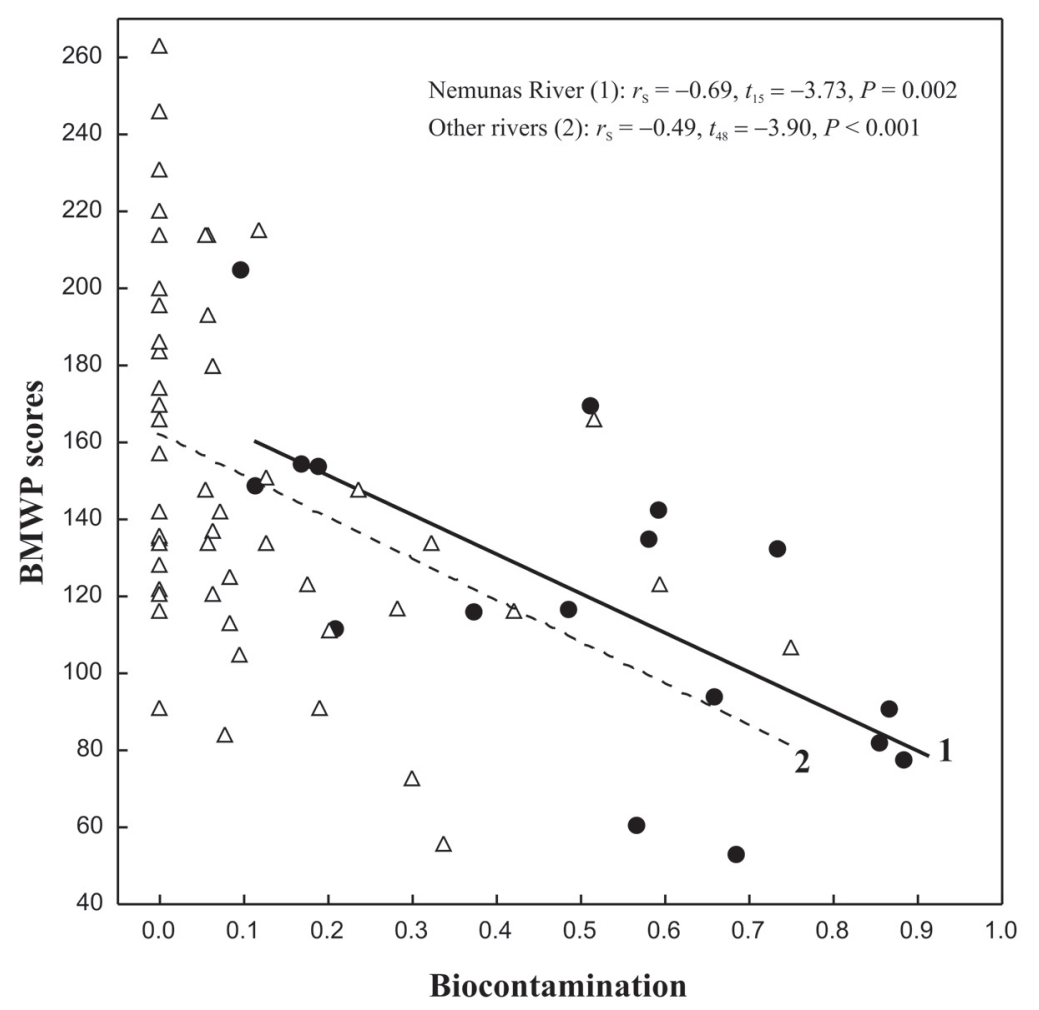

\section{Figure 4}

Correlation between estimates of biocontamination (abundance or disparity contamination index, whichever was larger) and ecological status as measured by BMWP scores for the Nemunas River (closed circles) and other surveyed rivers (open triangles). NB Spearman rank correlation values are provided.

\section{Figure 4}

Corrélation entre les estimations de la biocontamination (indice de contamination en abondance ou disparité) et l'état écologique tel que mesuré par les scores BMWP de la rivière Niémen (cercles fermés) et d'autres rivières étudiées (triangles vides). NB Les valeurs de corrélation de Spearman sont indiquées.

of NIMS-specific status of study sites, which can be further expanded to a larger scale assessment of aquatic ecosystems (Panovet al., 2009). The lower section of the Nemunas River and the stretch above the Kaunas WR (including the lowest stetches of the Minija and Neris rivers which empties into the Nemunas) were severely biocontaminated, indicating that new macroinvertebrate assemblages have arisen there due to NIMS establishment. Dramatic structural alterations almost inevitably must have led to changes in the functional organisation of riverine macroinvertebrate assemblages and entire ecosystem. Such an outcome of invaders' impact has been revealed for the Rhine River (Van Riel et al., 2006). The severe biocontamination of the lower Nemunas section located below the Kaunas WR may have been expected, as this river represents the northern branch of a Central European invasion corridor, which provided a pathway for the expansion of a few Ponto-Caspian invaders, L. naticoides, $D$. polymorpha and C. curvispinum, with the Ponto-Caspian peracaridan species P. robustoides, O. crassus, C. warpachowskyi, P. lacustris and $L$. benedeni all being deliberately introduced into the Kaunas WR during the 1960s. All these Ponto-Caspian newcomers together with the recent invader $O$. limosus were responsible for biocontamination of Lithuanian lotic systems. Another NIMS 'hotspot` was detected in the Šventoji River which, presumably, is subjected to human aided and natural invasions through the sea waters. Although the rivers of the Nemunas basin were more heavily affected by NIMS than surrounding rivers, an increase in NIMS impacts can also be predicted for many other Lithuanian rivers because rapid invaders' expansion in inland waters is ongoing (Arbačiauskas et al., 2011). 
The presence of NIMS invariably causes riverine macroinvertebrate assemblages to deviate from naturalness and therefore, biocontamination of inland waters should be considered, whenever implementing WFD for accurate quality classification of aquatic ecosystems (Cardoso and Free, 2008; Panov et al., 2009). Applying the biocontamination assessment scheme showed that the classification of NIMS-specific status into bad and poor classes was usually based on abundance contamination, while that for moderate and good classes was usually dependent upon disparity contamination (Figure 2). It seems that such a designation pattern may be general for European lotic systems (Arbačiauskas et al., 2008). Although richness contamination at family taxonomic rank and even at species level may be applied instead of disparity contamination for NIMS-specific status classification (e.g. Leuven et al., 2009; MacNeil et al., 2010), that could influence only the grading into good and moderate classes. Nevertheless, we argue for the precautionary principle in environment management (disparity contamination, i.e. ordinal richness contamination, is more sensitive at the initial stage of assemblage alteration in comparison to richness contamination at family or specific rank (see Figure 2 and Arbačiauskas et al., 2008)) and application of disparity contamination, as ultimately this measure may have an important underlying ecological meaning. For instance, richness at ordinal rank reflects the disparity of ecomorphological groups having different feeding patterns and could be interpreted as a proxy of functional structure of biological community. Interestingly, a similar conception of disparity is applied in the field of paleoecology (Foote, 1997).

Redundancy analysis of river biocontamination data revealed the significant spatial pattern which seems to be primarily shaped by the downstream expansion of Ponto-Caspian amphipods and mysids which were deliberately introduced into the Kaunas WR. The "pure" fraction of NIMS variation explained by the biocontamination metrics was at $9 \%$. Analysis also revealed that severe biocontamination in Lithuanian rivers was mainly associated with the pontogammarid $P$. robustoides. This species is able to suppress even the numbers of the other amphipod invaders, including a $C$. curvispinum. Indeed, previous studies have also shown $P$. robustoides to be a high-impact species capable of extermination of native amphipods (Arbačiauskas, 2005,2008 ) and of having an adverse impact on the richness, biodiversity and biomass of native lake littoral macroinvertebrate assemblages (Arbačiauskas and Gumuliauskaitè, 2007; Gumuliauskaitè and Arbačiauskas, 2008). The dramatic impact of another pontogammarid, Dikerogammarus villosus, on resident macroinvertebrate assemblages has been also well-documented elsewhere (Dick and Platvoet, 2000; Dick et al., 2002; Van Riel et al., 2006). This species exhibits flexible feeding modes from detritus consumption and grazing to predation on free swimming invertebrates and even fish larvae (Platvoet et al., 2009). Similar feeding plasticity is probably also a characteristic of $P$. robustoides, which preys on various macroinvertebrates and even mysids, as revealed by gut content analysis (Arbačiauskas, unpublished results).

At several sites in the middle section of the Nemunas River classified as severely biocontaminated, C. curvispinum was numerically dominant. At these sites $P$. robustoides was absent or scarce, whereas $C$. curvispinum was able to exhibit exceptionally high densities which caused the severe abundance contamination. Consequently this Ponto-Caspian amphipod can be attributed to a high-impact species, and that is supported by our analysis and other studies (Van Den Brink et al., 1993; Panov et al., 2009). Another NIMS which also may be considered a high-impact species was the snail $L$. naticoides. Although in our analysis the abundance of this snail was related to the disparity contamination, $L$. naticoides was among numerically dominant species in the lowest stretch of the Nemunas River. Its dominance of macroinvertebrate assemblages has also been observed elsewhere (Arbačiauskas et al., 2008).

These three non-indigenous species, the pontogammarid $P$. robustoides, the amphipod $C$. curvispinum and the snail $L$. naticoides, have been designated as high-impact species and assigned as 'blacklist' species for European inland waters (Panov et al., 2009) and our results support these conclusions.

The amphipod C. warpachowskyi tended to be more numerous at the sites of high disparity contamination. Whereas other amphipod invaders $O$. crassus and $G$. tigrinus were recorded only locally and there was insufficient data to draw firm conclusions on their impact on resident 
macroinvertebrate assemblages. The mysids $P$. lacustris and $L$. benedeni were found in places of high disparity contamination. At these sites the abundance of mysid (despite being probably underestimated due to the sampling method) was high enough for them to be present in the dip-net catches with considerable numbers. Mysid distribution in Lithuanian lotic systems, especially that of $P$. lacustris, is wider than that recorded by sampling method applied in this study (Arbačiauskas et al., 2011). Although the impact of Ponto-Caspian mysids on riverine benthic macroinvertebrate assemblages may not be substantial, both these mysid species may prey intensively on zooplankton and subsequently affect planktonic communities of stagnant waters (Lesutienè et al., 2007; Fink et al., 2011).

The crayfish $O$. limosus is an invasive high-impact species of environmental concern, especially in Lithuanian waters where its expansion is rapidly ongoing (Arbačiauskas et al., 2011). Another Orconectes species (Orconectes rusticus) has been found to be capable of significant community and ecosystem-level effects (Johnson et al., 2009). Invasive crayfish species have been reported for both direct and indirect detrimental impacts on ecosystems in European waters (see Westman, 2002). In our analysis O. limosus was negatively correlated with biocontamination metrics, simply because it was more abundant at river sites of low or moderate biocontamination, or where it was found alone. On the other hand, an assessment of non-indigenous crayfish presence on macroinvertebrate assemblage structure and function may need adjustment, as the impact of one crayfish specimen on a community may be much larger than that for another single individual of another NIMS group. The abundance of the Ponto-Caspian mussel $D$. polymorpha was unrelated to biocontamination levels and such a pattern may have been expected as the presence of this mussel in flowing waters depends mainly on recruitment from the source populations in stagnant waters and flow velocity. $D$. polymorpha has been repeatedly shown to be a high-impact species in stagnant waters (Karatayev et al., 2002), while its influence on riverine macroinvertebrate assemblages remains unexplored.

The strength of NIMS impacts on the structure and diversity of resident benthic macroinvertebrate assemblages evidently depends upon identity of invading species and their abundance. The most important common effect on macroinvertebrate assemblages we witnessed has implications for ecological quality assessment and this is that NIMS invasion can reduce the richness of native species which are sensitive to the quality of environment and currently serve as important bioindicators of water quality. In short, biocontamination can undermine the robustness and accuracy of current metrics of ecological quality. This was illustrated by the negative correlation between biocontamination and metrics such as EPT taxa richness and the BMWP score. However, the situation is complicated as some NIMS which were responsible for the highest levels of biocontamination, are rather intolerant to water pollution. For instance, P. robustoides is characterized as a species of high oxygen demand (Arbačiauskas, 2005), while the snail $L$. naticoides is declining in Poland due to water pollution, and is considered an endangered species (Zajac, 2005). In contrast, the spine-cheek crayfish which occurred in less biocontaminated places with higher estimates of ecological status is tolerant to habitat degradation and pollution (Lindqvist and Huner, 1999).

In the current analysis NIMS were excluded from calculation of BMWP scores, however, their inclusion had little effect on numeric values and did not change the revealed pattern (BMWP scores were calculations using Asterics 3.1.1 software available at http://www.fliessgewaesserbewertung.de). Our results also indicate that conventional ecological quality metrics such as ASPT score which are less sensitive to taxonomic richness than additive indices such as the BMWP may be less dependent upon the NIMS presence.

The macroinvertebrate sampling design applied in this study is comparable to the Assessment System for the Ecological Quality of streams and rivers throughout Europe using Benthic Macroinvertebrates methodology (AQEM Consortium, 2002). Thus, routine river macroinvertebrate monitoring data are sufficient with minimal extra effort to generate estimates of biocontamination providing robust information on deviation of macroinvertebrate assemblages from naturalness owing to NIMS presence. This important information is missing from most existing water quality monitoring programmes. We conclude that conventional metrics of biological quality which are largely based on native fauna may be influenced by biocontamination level 
and provide biased assessment of true ecological status in conventional sense. Therefore endorsing MacNeil et al. (2010) who also found the biocontamination assessment method to be practical and informative, we argue for the regular inclusion of biocontamination assessments into routine water quality monitoring programmes, alongside the established methods for evaluation of biological and chemical quality of inland waters. Recently, multimetric macroinvertebrate methods of quality assessment for ecological classification are under development (e.g. Dahl and Johnson, 2004; Gabriels et al., 2010). A possibility of incorporation of biocontamination metrics into these modern methods for a more holistic view of true status of inland waters should also be considered and tested.

\section{ACKNOWLEDGEMENTS}

The analysis was supported by the Research Council of Lithuania, Project No. LEK-18/2010. We are especially grateful to Calum MacNeil for valuable advice and substantial linguistic improvement of the manuscript. A draft of this manuscript also considerably benefited from the comments of anonymous reviewers.

\section{REFERENCES}

AQEM Consortium, 2002. Manual for the application of the AQEM system, A Comprehensive Method to Assess European Streams using Benthic Macroinvertebrates, developed for the Purpose of the Water Framework Directive, Version 1.0, February 2002 (available at http://www.aqem.de).

Arbačiauskas K., 2005. The distribution and local dispersal of Ponto-Caspian Peracarida in Lithuanian fresh waters with notes on Pontogammarus robustoides population establishment, abundance, and impact. Ocean. Hydro., 34, Suppl. 1, 93-113.

Arbačiauskas K., 2008. Amphipods of the Nemunas River and the Curonian Lagoon, the Baltic Sea basin: where and which native freshwater amphipods persist? Acta Zool. Litua., 18, 10-16.

Arbačiauskas K. and Gumuliauskaitè S., 2007. Invasion of the Baltic Sea basin by the Ponto-Caspian amphipod Pontogammarus robustoides and its ecological impact. In: Gherardi F. (ed.), Biological Invaders in inland waters: profiles, distribution and threats, Springer, Dordrecht, The Netherlands, 463-477.

Arbačiauskas K., Semenchenko V., Grabowski M., Leuven R.S.E.W., Paunovic M., Son M.O., Csanyi B., Gumuliauskaitė S., Konopacka A., Nehring S., van der Velde G., Vezhnovetz V. and Panov V.E., 2008. Assessment of biocontamination of benthic macroinvertebrate communities in European inland waterways. Aquat. Invas., 3, 211-230.

Arbačiauskas K., Višinskienè G., Smilgevičienè S. and Rakauskas V., 2011. Non-indigenous macroinvertebrate species in Lithuanian fresh waters, Part 1: Distributions, dispersal and future. Knowl. Managt. Aquatic Ecosyst., 402, DOI: 10.1051/kmae/2011075.

Armitage P.D., Moss D., Wright J.F. and Furse M.T., 1983. The performance of a new biological quality score system based on macroinvertebrates over a wide range of unpolluted running water sites. Water Res., 17, 333-347.

Cardoso A.C. and Free G., 2008. Incorporating invasive alien species into ecological assessment in the context of the Water Framework Directive. Aquat. Invas., 3, 361-366.

Dahl J. and Johnson R.K., 2004. A multimetric macroinvertebrate index for detecting organic pollution of streams in southern Sweden. Arch. Hydrobiol., 160, 487-513.

Dick J.T.A. and Platvoet D., 2000. Invading predatory crustacean Dikerogammarus villosus eliminates both native and exotic species. Proc. R. Soc. B, 267, 977-983.

Dick J.T.A., Platvoet D. and Kelly D.W., 2002. Predatory impact of the freshwater invader Dikerogammarus villosus (Crustacea: Amphipoda). Can. J. Fish. Aquat. Sci., 59, 1078-1084.

Elliott M., 2003. Biological pollutants and biological pollution - an increasing cause for concern. Mar. Pollut. Bull., 46, 275-280.

European Commission, 2000. Directive 2000/60/EC of the European Parliament and of the Council of 23 October 2000 establishing a framework for Community action in the field of water policy. Official Journal of the European Communities L327, 1-72. 
Fink P., Kottsieper A., Heynen M. and Borcherding J., 2011. Selective zooplanktivory of an invasive Ponto-Caspian mysid and possible consequences for the zooplankton community structure of invaded habitats. Aquat. Sci., DOI 10.1007/s00027-011-0210-y.

Foote M., 1997. The evolution of morphological diversity. Annu. Rev. Ecol. Syst., 28, 129-152.

Gabriels W., Lock K., De Pauw N. and Goethals P.L.M., 2010. Multimetric Macroinvertebrate Index Flanders (MMIF) for biological assessment of rivers and lakes in Flanders (Belgium). Limnologica, 40, 199-207.

Gailiušis B., Jablonskis J. and Kovalenkovienè M., 2001. Lithuanian rivers: hydrography and runoff, Lithuanian Energy Institute, Kaunas, 796 p. (in Lithuanian).

Genovese P., 2007. Towards a European strategy to halt biological invasions in inland waters. In: Gherardi F. (ed.), Biological Invaders in inland waters: profiles, distribution and threats, Springer, Dordrecht, The Netherlands, 627-637.

Gumuliauskaitè S. and Arbačiauskas K., 2008. The impact of the invasive Ponto-Caspian amphipod Pontogammarus robustoides on littoral communities in Lithuanian lakes. Hydrobiologia, 599, 127-134.

Johnson P.T.J., Olden J.D., Solomon C.T. and Vander Zanden M.J., 2009. Interactions among invaders: community and ecosystem effects of multiple invasive species in an experimental aquatic system. Oecologia, 159, 161-170.

Karatayev A.Y., Burlakova L.E. and Padilla D.K., 2002. Impacts of zebra mussels on aquatic communities and their role as ecosystem engineers. In: Leppakoski E., Gollasch S. and Olenin S. (eds.), Invasive Aquatic Species of Europe, Distribution, impacts and management, Kluwer Academic Publishers, Dordrecht, Boston, London, 433-446.

Kelly D.W., Bailey R.J.E., MacNeil C., Dick J.T.A. and McDonald R.A., 2006. Invasion by the amphipod Gammarus pulex alters community composition of native freshwater macroinvertebrates. Divers. Distrib., 12, 525-534.

Krisp H. and Maier G., 2005. Consumption of macroinvertebrates by invasive and native gammarids: a comparison. J. Limnol., 64, 55-59.

Legendre P. and Gallagher E.D., 2001. Ecologically meaningful transformations for ordination of species data. Oecologia, 129, 271-280.

Legendre P. and Legendre L., 1998. Numerical Ecology (2nd English ed). Elsevier, Amsterdam, The Netherlands, $852 \mathrm{p}$.

Lesutienè J., Gorokhova E., Gasiūnaitè Z.R. and Razinkovas A., 2007: Isotopic evidence for zooplankton as an important food source for the mysid Paramysis lacustris in the Curonian Lagoon, the SouthEastern Baltic Sea. Estuar. Coast. Shelf. Sci., 73, 73-80.

Leuven R.S.E.W., van der Velde G., Baijens I., Snijders J., van der Zwart C., Lenders H.J.R. and bij de Vaate A., 2009. The river Rhine: a global highway for dispersal of aquatic invasive species. Biol. Invasions, 11, 1989-2008.

Lindqvist O.V. and Huner J.V., 1999. Life-history characteristics of crayfish: What makes some of them good colonizers? In: Gherardi F. and Holdich D.M. (eds.), Crayfish in Europe as Alien Species, How to Make the Best of a Bad Situation? A.A. Balkema, Rotterdam, The Netherlands, 23-30.

MacNeil C. and Briffa M., 2009. Replacement of a native freshwater macroinvertebrate species by an invader; implications for biological water quality monitoring. Hydrobiologia, 635, 321-327.

MacNeil C., Briffa M., Leuven R.S.E.W., Gell F.R. and Selman R., 2010. An appraisal of a biocontamination assessment method for freshwater macroinvertebrate assemblages; a practical way to measure a significant biological pressure? Hydrobiologia, 638, 151-159.

Magnan P., Rodrigues M.A., Legendre P. and Lacasse S., 1994. Dietary variation in a freshwater fish species: Relative contributions of biotic interactions, abiotic factors, and spatial structure. Can. J. Fish. Aquat. Sci., 51, 2856-2865.

Molnar J.L., Gamboa R.L., Revenga C. and Spalding M.D., 2008. Assessing the global threat of invasive species to marine biodiversity. Front. Ecol. Environ., 6, 485-492

Panov V.E., Alexandrov B.G., Arbačiauskas K., Binimelis R., Copp G.H., Grabowski M., Lucy F., Leuven R.S.E.W., Nehring S., Paunović M., Semenchenko V. and Son M.O., 2009. Assessing the risks of aquatic species invasions via European inland waterways: from concepts to environmental indicators. Integr. Environ. Assess. Manag., 5, 110-126.

Platvoet D., van der Velde G., Dick J.T.A. and Li S.Q., 2009. Flexible omnivory in Dikerogammarus villosus (Sowinsky, 1894) (Amphipoda) - amphipod pilot species project (ampis) report 5. Crustaceana, 82, 703-720.

Ricciardi A., 2001. Facilitative interactions among aquatic invaders: is an "invasional meltdown" occurring in the Great Lakes? Can. J. Fish. Aquat. Sci., 58, 2513-2525. 
Ricciardi A., 2003. Predicting the impacts of an introduced species from its invasion history: an empirical approach applied to zebra mussel invasions. Freshw. Biol., 48, 972-981.

Rosenberg D.M. and Resh V.H. (eds.), 1993. Freshwater biomonitoring and benthic macroinvertebrates, Chapman and Hall, New York, $488 \mathrm{p}$.

Sala O.E., Chapin F.S., Armesto J.J., Berlow E., Bloomfield J., Dirzo R., Huber-Sanwald E., Huenneke L.F., Jackson R.B., Kinzig A., Leemans R., Lodge D.M., Mooney H.A., Oesterheld M., Poff N.L., Sykes M.T., Walker B.H., Walker M. and Wall D.H., 2000. Global biodiversity scenarios for the year 2100. Science, 287, 1770-1774.

Spencer C.N., McClelland B.R. and Stanford J.A., 1991. Schrimp stocking, salmon collapse, and eagle displacement. Cascading interactions in the food web of a large aquatic ecosystem. BioScience, $41,14-21$.

Van den Brink F.W.B., Van der Velde G. and Bij de Vaate A., 1993. Ecological aspects, explosive range extension and impact of a mass invader, Corophium curvispinum Sars, 1895 (Crustacea: Amphipoda), in the lower Rhine (The Netherlands). Oecologia, 93, 224-232.

Van Riel M.C., van der Velde G., Rajagopal S., Marguillier S., Dehairs F. and de Vaate A.B., 2006. Trophic relationships in the Rhine food web during invasion and after establishment of the Ponto-Caspian invader Dikerogammarus villosus. Hydrobiologia, 565, 39-58.

Vitousek P.M., Mooney H.A., Lubchenco J. and Melillo J.M., 1997. Human domination of earth's ecosystems. Science, 277, 494-499.

Westman K., 2002. Alien crayfish in Europe: negative and positive impacts and interactions with native crayfish. In: Leppakoski E., Gollasch S. and Olenin S. (eds.), Invasive Aquatic Species of Europe, Distribution, impacts and management, Kluwer Academic Publishers, Dordrecht, Boston, London, 76-95.

Wright J.F., Moss D., Armitage P.D. and Furse M.T., 1984. A preliminary classification of running-water sites in Great Britain based on macro-invertebrate species and the prediction of community type using environmental data. Freshw. Biol., 14, 221-256.

Zajac K., 2005. Threatened molluscs of Poland. Tentacle, 13, 13-15.

Zuur A.F., leno E.N. and Smith G.M., 2007. Analysing Ecological Data, Springer, 672 p. 
Annex. River study sites and metrics of biocontamination and ecological quality: number of identified taxa (T), number of non-indigenous macroinvertebrate species (NIMS) $\left(T_{N}\right)$, abundance of the most numerous NIMS $\left(N_{N}\right.$, ind. $\left.10 \mathrm{~min}^{-1}\right)$, number of all orders $(O)$, number of non-indigenous orders $\left(O_{N}\right)$, abundance contamination index $(A C)$, disparity contamination index (DC), NIMS-specific status of naturalness, i.e. biocontamination class (BCC), BMWP and ASPT scores, and number of EPT taxa. NB Study sites for each river are arranged in upstream order; NIMS which were most numerous at study sites are indicated in Figure 1.

\begin{tabular}{|c|c|c|c|c|c|c|c|c|c|c|c|c|c|}
\hline No. & Latitude, N & Longitude, E & $\mathrm{T}$ & $\mathrm{T}_{\mathrm{N}}$ & $\mathrm{N}_{\mathrm{N}}$ & $\mathrm{O}$ & $\mathrm{O}_{\mathrm{N}}$ & $\mathrm{AC}$ & DC & $\mathrm{BCC}$ & BMWP & ASPT & EPT \\
\hline 1 & 2 & 3 & 4 & 5 & 6 & 7 & 8 & 9 & 10 & 11 & 12 & 13 & 14 \\
\hline \multicolumn{14}{|c|}{ Nemunas River } \\
\hline 1 & $55^{\circ} 17^{\prime} 44.5^{\prime \prime}$ & $21^{\circ} 23^{\prime} 08.9^{\prime \prime}$ & 25 & 7 & 76 & 14 & 4 & 0.684 & 0.308 & 4 & 53 & 4.08 & 2 \\
\hline 2 & $55^{\circ} 05^{\prime} 48.9^{\prime \prime}$ & $21^{\circ} 51^{\prime} 37.3^{\prime \prime}$ & 27 & 8 & 103 & 14 & 4 & 0.852 & 0.286 & 4 & 82 & 5.47 & 4 \\
\hline 3 & $55^{\circ} 04^{\prime} 18.9^{\prime \prime}$ & $22^{\circ} 02^{\prime} 31.0^{\prime \prime}$ & 30 & 8 & 87 & 16 & 5 & 0.864 & 0.312 & 4 & 91 & 6.07 & 6 \\
\hline 4 & $55^{\circ} 03^{\prime} 17.8^{\prime \prime}$ & $22^{\circ} 23^{\prime} 27.2^{\prime \prime}$ & 35 & 7 & 113 & 14 & 5 & 0.657 & 0.286 & 4 & 94 & 5.53 & 4 \\
\hline 5 & $55^{\circ} 05^{\prime} 03.7^{\prime \prime}$ & $22^{\circ} 55^{\prime} 13.7^{\prime \prime}$ & 39 & 5 & 299 & 18 & 4 & 0.590 & 0.235 & 4 & 143 & 5.50 & 8 \\
\hline 6 & $55^{\circ} 04^{\prime} 34.2^{\prime \prime}$ & $23^{\circ} 23^{\prime} 26.7^{\prime \prime}$ & 59 & 7 & 156 & 18 & 5 & 0.509 & 0.294 & 4 & 170 & 5.67 & 9 \\
\hline 7 & $54^{\circ} 54^{\prime} 19.8^{\prime \prime}$ & $23^{\circ} 50^{\prime} 03.2^{\prime \prime}$ & 28 & 3 & 205 & 15 & 3 & 0.565 & 0.214 & 4 & 61 & 4.07 & 3 \\
\hline 8 & $54^{\circ} 36^{\prime} 11.0^{\prime \prime}$ & $24^{\circ} 00^{\prime} 08.3^{\prime \prime}$ & 22 & 4 & 211 & 12 & 2 & 0.883 & 0.167 & 4 & 78 & 5.20 & 5 \\
\hline 9 & $54^{\circ} 33^{\prime} 22.2^{\prime \prime}$ & $23^{\circ} 55^{\prime} 48.0^{\prime \prime}$ & 37 & 4 & 4492 & 16 & 2 & 0.733 & 0.125 & 4 & 133 & 5.54 & 7 \\
\hline 10 & $54^{\circ} 29^{\prime} 27.3^{\prime \prime}$ & $23^{\circ} 59^{\prime} 17.4^{\prime \prime}$ & 36 & 4 & 17 & 17 & 3 & 0.207 & 0.176 & 3 & 112 & 5.09 & 4 \\
\hline 11 & $54^{\circ} 32^{\prime} 49.7^{\prime \prime}$ & $24^{\circ} 00^{\prime} 58.0^{\prime \prime}$ & 43 & 2 & 79 & 17 & 2 & 0.058 & 0.111 & 2 & 149 & 5.32 & 9 \\
\hline 12 & $54^{\circ} 30^{\prime} 44.8^{\prime \prime}$ & $24^{\circ} 03^{\prime} 24.2^{\prime \prime}$ & 33 & 3 & 733 & 16 & 3 & 0.372 & 0.188 & 3 & 116 & 5.27 & 5 \\
\hline 13 & $54^{\circ} 26^{\prime} 05.8^{\prime \prime}$ & $24^{\circ} 04^{\prime} 13.0^{\prime \prime}$ & 47 & 4 & 2680 & 19 & 4 & 0.580 & 0.211 & 4 & 135 & 5.00 & 9 \\
\hline 14 & $54^{\circ} 21^{\prime} 59.6^{\prime \prime}$ & $24^{\circ} 05^{\prime} 31.0^{\prime \prime}$ & 32 & 3 & 112 & 17 & 3 & 0.483 & 0.188 & 3 & 117 & 5.85 & 8 \\
\hline 15 & $54^{\circ} 09^{\prime} 35.8^{\prime \prime}$ & $24^{\circ} 10^{\prime} 36.8^{\prime \prime}$ & 63 & 3 & 268 & 21 & 2 & 0.058 & 0.095 & 1 & 205 & 5.54 & 22 \\
\hline 16 & $54^{\circ} 09^{\prime} 16.2^{\prime \prime}$ & $24^{\circ} 10^{\prime} 48.7^{\prime \prime}$ & 46 & 2 & 55 & 19 & 2 & 0.188 & 0.111 & 2 & 154 & 5.31 & 10 \\
\hline 17 & $54^{\circ} 00^{\prime} 54.1^{\prime \prime}$ & $23^{\circ} 56^{\prime} 04.9^{\prime \prime}$ & 43 & 3 & 35 & 18 & 3 & 0.073 & 0.167 & 2 & 155 & 5.34 & 9 \\
\hline \multicolumn{14}{|c|}{ Minija River } \\
\hline 18 & $55^{\circ} 21^{\prime} 27,4^{\prime \prime}$ & $21^{\circ} 17^{\prime} 02.3^{\prime \prime}$ & 42 & 8 & 47 & 18 & 5 & 0.592 & 0.278 & 4 & 123 & 5.13 & 5 \\
\hline 19 & $55^{\circ} 33^{\prime} 18.7^{\prime \prime}$ & $21^{\circ} 19^{\prime} 37.7^{\prime \prime}$ & 40 & 1 & 1 & 16 & 1 & 0.006 & 0.063 & 1 & 137 & 5.48 & 9 \\
\hline 20 & $55^{\circ} 46^{\prime} 41.1^{\prime \prime}$ & $21^{\circ} 25^{\prime} 35.6^{\prime \prime}$ & 29 & 0 & & 12 & & 0 & 0 & 0 & 135 & 6.14 & 10 \\
\hline 21 & $55^{\circ} 52^{\prime} 55.1^{\prime \prime}$ & $21^{\circ} 43^{\prime} 32.6^{\prime \prime}$ & 38 & 0 & & 14 & & 0 & 0 & 0 & 184 & 6.35 & 14 \\
\hline 22 & $55^{\circ} 50^{\prime} 41.3^{\prime \prime}$ & $22^{\circ} 11^{\prime} 55.5^{\prime \prime}$ & 43 & 0 & & 11 & & 0 & 0 & 0 & 196 & 6.53 & 15 \\
\hline \multicolumn{14}{|c|}{ Šešupė River } \\
\hline 23 & $54^{\circ} 45^{\prime} 52.7^{\prime \prime}$ & $22^{\circ} 52^{\prime} 45.3^{\prime \prime}$ & 32 & 4 & 102 & 15 & 3 & 0.420 & 0.200 & 3 & 116 & 5.80 & 8 \\
\hline 24 & $54^{\circ} 42^{\prime} 41.5^{\prime \prime}$ & $23^{\circ} 13^{\prime} 18.8^{\prime \prime}$ & 33 & 1 & 29 & 15 & 1 & 0.322 & 0.071 & 3 & 134 & 5.36 & 5 \\
\hline 25 & $54^{\circ} 37^{\prime} 09.0^{\prime \prime}$ & $23^{\circ} 23^{\prime} 46.8^{\prime \prime}$ & 22 & 2 & 69 & 12 & 2 & 0.300 & 0.167 & 3 & 73 & 4.87 & 1 \\
\hline 26 & $54^{\circ} 21^{\prime} 25.3^{\prime \prime}$ & $23^{\circ} 03^{\prime} 50.1^{\prime \prime}$ & 31 & 1 & 5 & 12 & 1 & 0.034 & 0.083 & 1 & 125 & 6.25 & 11 \\
\hline \multicolumn{14}{|c|}{ Nevėžis River } \\
\hline 27 & $54^{\circ} 55^{\prime} 58.1^{\prime \prime}$ & $23^{\circ} 47^{\prime} 39.9^{\prime \prime}$ & 46 & 5 & 25 & 17 & 4 & 0.205 & 0.235 & 3 & 148 & 5.48 & 8 \\
\hline 28 & $55^{\circ} 12^{\prime} 55.5^{\prime \prime}$ & $23^{\circ} 54^{\prime} 45.0^{\prime \prime}$ & 40 & 1 & 6 & 16 & 1 & 0.025 & 0.063 & 1 & 180 & 5.81 & 11 \\
\hline 29 & $55^{\circ} 30^{\prime} 51.1^{\prime \prime}$ & $24^{\circ} 04^{\prime} 29.9^{\prime \prime}$ & 45 & 2 & 23 & 16 & 2 & 0.088 & 0.125 & 2 & 151 & 5.59 & 12 \\
\hline 30 & $55^{\circ} 44^{\prime} 07.9^{\prime \prime}$ & $24^{\circ} 14^{\prime} 04.3^{\prime \prime}$ & 37 & 1 & 4 & 14 & 1 & 0.009 & 0.071 & 1 & 142 & 5.92 & 11 \\
\hline 31 & $55^{\circ} 37^{\prime} 39.2^{\prime \prime}$ & $24^{\circ} 36^{\prime} 16.8^{\prime \prime}$ & 33 & 0 & & 11 & & 0 & 0 & 0 & 142 & 5.46 & 8 \\
\hline \multicolumn{14}{|c|}{ Neris River } \\
\hline 32 & $54^{\circ} 55^{\prime} 57.5^{\prime \prime}$ & $23^{\circ} 54^{\prime} 40.4^{\prime \prime}$ & 36 & 3 & 494 & 15 & 3 & 0.749 & 0.267 & 4 & 107 & 4.86 & 5 \\
\hline 33 & $55^{\circ} 04^{\prime} 30.0^{\prime \prime}$ & $24^{\circ} 17^{\prime} 30.8^{\prime \prime}$ & 29 & 1 & 1 & 16 & 1 & 0.009 & 0.063 & 1 & 121 & 5.76 & 8 \\
\hline 34 & $54^{\circ} 59^{\prime} 17.1^{\prime \prime}$ & $24^{\circ} 33^{\prime} 28.2^{\prime \prime}$ & 26 & 1 & 1 & 12 & 1 & 0.009 & 0.083 & 1 & 113 & 5.95 & 5 \\
\hline 35 & $54^{\circ} 48^{\prime} 11.2^{\prime \prime}$ & $24^{\circ} 55^{\prime} 12.3^{\prime \prime}$ & 27 & 0 & & 11 & & 0 & 0 & 0 & 91 & 5.35 & 4 \\
\hline 36 & $54^{\circ} 44^{\prime} 41.5^{\prime \prime}$ & $25^{\circ} 17^{\prime} 31.4^{\prime \prime}$ & 25 & 1 & 1 & 13 & 1 & 0.008 & 0.077 & 1 & 84 & 5.06 & 4 \\
\hline 37 & $54^{\circ} 50^{\prime} 28.8^{\prime \prime}$ & $25^{\circ} 32^{\prime} 08.9^{\prime \prime}$ & 34 & 0 & & 14 & & 0 & 0 & 0 & 136 & 5.91 & 8 \\
\hline 38 & $54^{\circ} 50^{\prime} 17.6^{\prime \prime}$ & $25^{\circ} 44^{\prime} 00.7^{\prime \prime}$ & 32 & 0 & & 14 & & 0 & 0 & 0 & 116 & 5.52 & 4 \\
\hline
\end{tabular}




\begin{tabular}{|c|c|c|c|c|c|c|c|c|c|c|c|c|c|}
\hline 1 & 2 & 3 & 4 & 5 & 6 & 7 & 8 & 9 & 10 & 11 & 12 & 13 & 14 \\
\hline \multicolumn{14}{|c|}{ Merkys River } \\
\hline 39 & $54^{\circ} 08^{\prime} 41.0^{\prime \prime}$ & $24^{\circ} 12^{\prime} 23.9^{\prime \prime}$ & 69 & 2 & 8 & 17 & 2 & 0.011 & 0.118 & 2 & 215 & 5.97 & 26 \\
\hline \multicolumn{14}{|c|}{ Baltoji Ančia River } \\
\hline 40 & $53^{\circ} 57^{\prime} 14.9^{\prime \prime}$ & $23^{\circ} 50^{\prime} 03.1^{\prime \prime}$ & 35 & 3 & 5 & 17 & 3 & 0.072 & 0.176 & 2 & 123 & 5.59 & 6 \\
\hline 41 & $53^{\circ} 59^{\prime} 07.1^{\prime \prime}$ & $23^{\circ} 39^{\prime} 28.8^{\prime \prime}$ & 20 & 1 & 1 & 11 & 1 & 0.023 & 0.093 & 1 & 105 & 6.56 & 6 \\
\hline \multicolumn{14}{|c|}{ Žeimena River } \\
\hline 42 & $54^{\circ} 54^{\prime} 04.7^{\prime \prime}$ & $25^{\circ} 38^{\prime} 31.0^{\prime \prime}$ & 41 & 0 & & 13 & & 0 & 0 & 0 & 157 & 5.82 & 12 \\
\hline 43 & $54^{\circ} 59^{\prime} 05.1^{\prime \prime}$ & $25^{\circ} 46^{\prime} 20.4^{\prime \prime}$ & 31 & 2 & 4 & 11 & 2 & 0.106 & 0.182 & 2 & 111 & 6.53 & 13 \\
\hline 44 & $55^{\circ} 09^{\prime} 13.3^{\prime \prime}$ & $25^{\circ} 58^{\prime} 59.7^{\prime \prime}$ & 45 & 0 & & 14 & & 0 & 0 & 0 & 166 & 5.72 & 14 \\
\hline 45 & $55^{\circ} 15^{\prime} 10.3^{\prime \prime}$ & $25^{\circ} 59^{\prime} 29.2^{\prime \prime}$ & 31 & 2 & 30 & 13 & 2 & 0.281 & 0.154 & 3 & 117 & 5.57 & 8 \\
\hline \multicolumn{14}{|c|}{ ventoji River } \\
\hline 46 & $56^{\circ} 01^{\prime} 44.9^{\prime \prime}$ & $21^{\circ} 04^{\prime} 23.7^{\prime \prime}$ & 33 & 6 & 51 & 21 & 4 & 0.123 & 0.190 & 2 & 91 & 4.33 & 1 \\
\hline 47 & $56^{\circ} 01^{\prime} 52.0^{\prime \prime}$ & $21^{\circ} 05^{\prime} 17.2^{\prime \prime}$ & 47 & 5 & 285 & 19 & 3 & 0.515 & 0.158 & 4 & 166 & 5.72 & 11 \\
\hline 48 & $56^{\circ} 02^{\prime} 49.3^{\prime \prime}$ & $21^{\circ} 07^{\prime} 47.6^{\prime \prime}$ & 65 & 1 & 9 & 18 & 1 & 0.005 & 0.056 & 1 & 214 & 5.78 & 19 \\
\hline 49 & $56^{\circ} 12^{\prime} 46.4^{\prime \prime}$ & $21^{\circ} 20^{\prime} 31.4^{\prime \prime}$ & 40 & 0 & & 15 & & 0 & 0 & 0 & 122 & 4.88 & 7 \\
\hline \multicolumn{14}{|c|}{ Venta River } \\
\hline 50 & $56^{\circ} 20^{\prime} 19.1^{\prime \prime}$ & $22^{\circ} 14^{\prime} 14.8^{\prime \prime}$ & 66 & 0 & & 20 & & 0 & 0 & 0 & 220 & 5.79 & 15 \\
\hline 51 & $56^{\circ} 16^{\prime} 38.0^{\prime \prime}$ & $22^{\circ} 22^{\prime} 14.8^{\prime \prime}$ & 55 & 0 & & 18 & & 0 & 0 & 0 & 170 & 5.31 & 13 \\
\hline 52 & $56^{\circ} 08^{\prime} 25.8^{\prime \prime}$ & $22^{\circ} 47^{\prime} 59.1^{\prime \prime}$ & 54 & 1 & 13 & 18 & 1 & 0.029 & 0.056 & 1 & 193 & 5.85 & 14 \\
\hline 53 & $55^{\circ} 49^{\prime} 45.9^{\prime \prime}$ & $22^{\circ} 51^{\prime} 43.8^{\prime \prime}$ & 51 & 0 & & 13 & & 0 & 0 & 0 & 174 & 6.00 & 17 \\
\hline \multicolumn{14}{|c|}{ Mūša River } \\
\hline 54 & $56^{\circ} 09^{\prime} 09.1^{\prime \prime}$ & $24^{\circ} 27^{\prime} 03.4^{\prime \prime}$ & 49 & 1 & 17 & 19 & 1 & 0.008 & 0.053 & 1 & 148 & 5.29 & 11 \\
\hline 55 & $56^{\circ} 02^{\prime} 44.3^{\prime \prime}$ & $24^{\circ} 13^{\prime} 11.0 "$ & 42 & 0 & & 16 & & 0 & 0 & 0 & 121 & 5.04 & 10 \\
\hline 56 & $56^{\circ} 01^{\prime} 51.7^{\prime \prime}$ & $23^{\circ} 55^{\prime} 26.0^{\prime \prime}$ & 29 & 0 & & 15 & & 0 & 0 & 0 & 134 & 5.58 & 10 \\
\hline 57 & $56^{\circ} 09^{\prime} 43.2^{\prime \prime}$ & $23^{\circ} 22^{\prime} 19.4^{\prime \prime}$ & 64 & 0 & & 17 & & 0 & 0 & 0 & 214 & 5.78 & 16 \\
\hline \multicolumn{14}{|c|}{ Lèvuo River } \\
\hline 58 & $56^{\circ} 01^{\prime} 57.7^{\prime \prime}$ & $24^{\circ} 19^{\prime} 54.8^{\prime \prime}$ & 44 & 1 & 6 & 18 & 1 & 0.007 & 0.056 & 1 & 134 & 5.15 & 8 \\
\hline 59 & $55^{\circ} 50^{\prime} 14.4 \prime$ & $24^{\circ} 15^{\prime} 33.3^{\prime \prime}$ & 66 & 0 & & 17 & & 0 & 0 & 0 & 263 & 5.98 & 19 \\
\hline 60 & $55^{\circ} 47^{\prime} 50.5^{\prime \prime}$ & $24^{\circ} 20^{\prime} 00.4^{\prime \prime}$ & 12 & 1 & 37 & 7 & 1 & 0.336 & 0.143 & 3 & 56 & 6.22 & 7 \\
\hline \multicolumn{14}{|c|}{ Nemunèlis River } \\
\hline 61 & $56^{\circ} 23^{\prime} 07.3^{\prime \prime}$ & $24^{\circ} 42^{\prime} 02.9^{\prime \prime}$ & 59 & 0 & & 18 & & 0 & 0 & 0 & 246 & 6.15 & 17 \\
\hline 62 & $56^{\circ} 17^{\prime} 54.5^{\prime \prime}$ & $24^{\circ} 59^{\prime} 31.3^{\prime \prime}$ & 47 & 0 & & 14 & & 0 & 0 & 0 & 200 & 6.25 & 16 \\
\hline 63 & $56^{\circ} 08^{\prime} 20.7^{\prime \prime}$ & $25^{\circ} 09^{\prime} 29.1^{\prime \prime}$ & 61 & 0 & & 17 & & 0 & 0 & 0 & 231 & 5.78 & 18 \\
\hline 44 & $56^{\circ} 02^{\prime} 17.5^{\prime \prime}$ & $25^{\circ} 22^{\prime} 58.5^{\prime \prime}$ & 60 & 0 & & 16 & & 0 & 0 & 0 & 186 & 5.47 & 18 \\
\hline 65 & $55^{\circ} 56^{\prime} 40.2^{\prime \prime}$ & $25^{\circ} 26^{\prime} 27.6^{\prime \prime}$ & 43 & 0 & & 17 & & 0 & 0 & 0 & 128 & 4.92 & 8 \\
\hline \multicolumn{14}{|c|}{ Dysna River } \\
\hline 66 & $55^{\circ} 21^{\prime} 18.4^{\prime \prime}$ & $26^{\circ} 25^{\prime} 33.2^{\prime \prime}$ & 55 & 1 & 2 & 19 & 1 & 0.002 & 0.053 & 1 & 214 & 5.63 & 14 \\
\hline 67 & $55^{\circ} 25^{\prime} 00.3^{\prime \prime}$ & $26^{\circ} 23^{\prime} 04.3^{\prime \prime}$ & 31 & 2 & 5 & 16 & 2 & 0.008 & 0.125 & 2 & 134 & 5.58 & 10 \\
\hline
\end{tabular}

